\title{
Future of Human rights in Europe: Opportunity or Threat
}

\author{
Mehdi Abbasi Sarmadi \\ Kharazmi University, Law and Political Sciences Department \\ Reza Asadi Khomami \\ University of Guilan Department of law, \\ Master Degree in International law
}

\begin{abstract}
One of the fundamental pillars for the idea of unity in the Europe has been Human rights issues.in the introduction of the text of the European Convention of Human Rights and Fundamental Freedoms has been Emphasized that The aim of the Council of Europe is to create more unity between its members and protection and further realization of human rights and fundamental freedoms, are ways to reach its fulfillment. The flood of refugees to European countries has created problems for them; Anti-immigrant movement in Europe is emerging which May be undermined the fundamental freedoms and human rights considered by European countries that compiled the convention. On the other hand; whisper of separation from united Europe In some countries is heard. Activity of anti-immigrant groups can lead to reduction of freedom and can help to those countries which have a tendency to separate. Just as maintain and realization of human rights created united Europe; whether human rights is opportunity or threat for the united Europe? The article opens with a discussion of the role of human rights in Formation of European Union; it then offers a critique of policies that reduced the Fundamental Freedoms. The article closes with a discussion of the future of human rights in Europe.
\end{abstract}

Keywords: Fundamental Freedoms; Human Rights; anti-immigrant groups; united Europe

\section{Role of human right in Europe}

About the background of Adoption of regulations concerning protection of human rights in Europe, It can be stated "following the atrocities that occurred during World War II, it appeared a motivation for conclusion of an agreement to protection of people's individual rights in Europe" (Akhlaghi, Eshtiagh, Parvizian, 2001,p 175). After Second World War II, thought about the forming of the united Europe, "which at first, it had introduced as an ultra-national government "(Kadkhodayi, 2001, p14). Appeared with glory of brightness among the political intellectuals and legal experts, "because for prevailing over difficulties arising from the war, European governments found that they need to establishment and spread regional collaboration" (Taghizadeh Ansari, 2008). But the main subject that encouraged to this convergence was the process of violation of fundamental measures of human rights which was accepted in the early documents of human rights as an example Universal Declaration of Human Rights. Generally, the human rights issue has been one of the fundamental pillars for the idea of unity in the Europe. It must be stressed that "human rights was not one of the primary objectives of the drafters of the unification of Europe and European countries for economic reasons, mainly, established European Union. But with spreading of European objectives and increasing the number of Member States, Shortcomings were felt in the area of human rights which this raises prepare the way for approving various regulations to supporting of this kind of rights" (Naghibi mofrad, 2010, p85). From 20th march 1952 till 4th may 2004 European Convention on the Protection of Human Rights and Fundamental Freedoms which was approved in 1950 and Entered into force in 1953 has been modified by approving 14 protocols. "At first, the intention was supporting of civil and political rights In comparison with economic, social and cultural rights" (sidabras and dziautas v. Lithuania, para, 47). This matter shows an important measure for implication of special aspects of Universal Declaration of Human Rights. In the introduction of combined text of the Convention, Edited 2004 is mentioned to complementary role of the convention in execution of Universal Declaration of Human Rights; that is to say :".... Due to the Universal Declaration of Human Rights.... Due to the aim of already mentioned Declaration is to guarantee of General and effective recognition and observance the rights which It has been announced...." (Amirardjmand, 
2009,p 93). Thus, it is shown that Completion and implementation of human rights principles is indicative of its approach by remembrance of Universal Declaration of Human Rights in the text of convention.in fact: "European convention of human rights, is first step in enforcing of the human rights rules in Universal Declaration of Human Rights, because when it ratified in 1948,it was clear that it never Going beyond a Declaration and an global perception and understanding about human rights Mentioned in it and It takes years to executive and binding mechanisms to be found (Mehrpour, 2004,p.183) "there are two main differences between Universal Declaration of Human Rights and European convention :" first, European treaty is a regional treaty and its subject is ratified as a convention, not as a declaration. Second, there is an institution for sanction of the rights enumerated in the Convention that called European Court of Human Rights which Universal Declaration of Human Rights has not such a direct sanction" ( Ghaemmagham farahani, 2002,pp 181-182). Minimum standards of human rights which in More than 50 years have been accepted by all European countries, is expressed in the convention. During the years, standards and concepts of human rights are developed and somehow that in some aspects, convention could not be Responsible for human rights issues related to the present time. "Despite the ratification of protocols were annexed it, for compensate for this dimension and concept development and also despite struggles has done by European Court of Human Rights for interpretation of these documents as "Dynamic and Live documents "In order to the conceptual development of these norms, still Many scientists criticized the provisions set forth in this Convention and thought it has expanded restrictions. But with all considered criticisms, The European Convention on Human Rights Had extraordinary impact on Development of legislation and supporting method in the field of human rights protection in Europe. The convention, at the present, is recognized as a very important and more successful regional system in protection of human rights and fundamental freedoms which is very important because of its mechanisms for implementation and the number of members. The convention, also, is defined as fundamental rights in Europe (Leach, 2005, p.6). " although The European Convention on Human Rights was not the first international document about human rights, but it can be considered as the first human rights instrument which has foreseen Judicial body to monitor and legal control the performance of an international contract. Obviously, Arrangements conducted in domestic law are the best and most effective Means to protect the rights and freedoms of individuals, but cannot be denied that this arrangement always were not enough sufficient and therefor Trans-national courts and authorities, can perform remarkable supportive role in Guarantee and protect the rights of citizens. European Court of Human Rights has played a significant role not only in promoting human rights in Europe but also in growth and evolution international law" ( seyed fatemi, 2000). The difference between The European Convention on Human Rights and other international human rights document is in "practical and effective method in supporting of human rights as style that has foreseen in its context" ( Sammer, 2001,p.5).

\section{Substantive rights set out in the Convention}

Substantive rights are explained from articles 2 till article 18 which briefly are right to life and necessity to respect it, Prohibition of torture and inhumane punishment, The prohibition of slavery and exploitation and forced labor, Right to liberty and personal security, Non-personal custody ,..., Respect the presumption of innocence, The principle of legality of crime and punishment, The right to freedom of thought, conscience, religion, freedom of speech, assembly and participation in it. As a matter of fact, European governments with the approval of the European Convention on Human Rights, the human rights which expressed in Universal Declaration of Human Rights were molded as a contract. So expressed substantive rights in convention are similar and based on Declaration of Human Rights.in the introduction of convention is emphasized that "the aim of the council of Europe is the achievement of greater unity between its members and that one of methods by which that aim is to be pursued is the maintenance and further realization of human rights and fundamental freedoms". So they needed to consider an executive mechanism for binding of the convention, Therefore European court of human rights is considered as a mechanism for its sanction which establishment of the court is expressed in article 19. The court has established for "to ensure the observance of the engagements undertaken by the high contracting parties in the convention and the protocols..." ( article 19 of European convention on human rights) all individuals who live in the sovereign territory of members of the Convention, in the case of violation of human rights, accordance with the conditions of convention, are allowed to complain against any member state. This is an effective and sufficient mechanism for Practical protection of human rights. On 1st Nov. 1998 by the ratification of Protocol No. 11, many important Changes and reforms have been occurred in executive mechanism of the European Convention on Human Rights and independent tribunal which increased practical efficiency of convention. Till this date the court's jurisdiction was not compulsory, states either could act according to article 25, accept petition individual Compensation or according to article 46 accept The competence of the European Court of Human Rights. But after that jurisdiction of court was compelled. "The emergence of a regional system could be deliberate and formed according to states premeditated, but in most cases, it forms Unintentional and Caused by various 
international conditions. Accordingly, economic, political, social and security factors are effective in realizing a regional system" ( Bjorn hettne, 2001,pp.204-212) .The mentioned reforms illustrate the tendency to unity and convergence and Indicative regional Interaction in Europe and human rights was one of factors for forming a union.

\section{Policies that reduce the fundamental freedoms}

Europe in the 21th century is very different from that one in last century. Enlargement had its vociferous detractors same as any other developments in Europe. Bringing cases to trial is one of problems which cause many critiques to Justice Systems of some European countries. The London-based organization Fair Trials International which works for fair trials according to international standards of justice and the international law firm Clifford Chance, which was formed in 1987 by the merger of two London-based law firms, Clifford Turner and Coward Chance, collected some information that cover a five-year period between 2007 and summer of 2001. A number of the European Union's essential values are Human rights, democracy and the rule of law principle. They were embedded in original treaty and have been strengthened by the adoption of a charter on fundamental rights. The EUs human rights policy is focused around civil, political, economic, social and cultural rights (www.humanrights.dk). States on the eastern fringes of the union emerge as serial offenders in a comparative study of breaches of individuals' right to liberty and a fair trial recorded by the European court of human rights(www.theguardian.com, 2012). Greece, Bulgaria, Poland and Romania are the worst European Union countries at delivering justice through criminal trials, according to an independent survey of the union's courts (www.theguardian.com, 2012). Statistics show an increase in human rights violations in European countries. There were 37 violations of the right to a fair criminal trial in EU states in 2007, and 75 in 2011 - an increase of more than 100\%(www.theguardian.com, 2012). Greece with 108 cases and England with 12 cases of violation of human rights had highest and lowest number of violations for breaching either article 5 (the right to liberty) and article 6 (the right to a fair trial) of the European convention on human rights over the five-year period. Bulgaria with 92 violations recorded by the ECHR, Poland with 67 breaches, and Romania with 49 violations are other countries which had more violation than others (www.theguardian.com, 2012). As statistics show violation of human rights in countries with more economic problems are higher than rich countries. By increasing poverty in any country, it least able to deliver fair and timely justice. Another policy that reduces the fundamental freedoms is fight against terrorism which by some of European states cause the limitation or reduction of human rights and fundamental freedoms in some cases. Fight against terrorism threatens fundamental freedoms in two aspects. First, is restriction of individual rights and freedom because of Security risks and second, is Xenophobic and anti-Muslim arguments because most of terrorists are from Muslim countries or people who are Muslim origin. Restrictions on individual liberties causes reduction in rights which the population is entitled to fully enjoy without government intrusion, certainly in conjunction with the need for public order, national security, the preservation of moral values, as well as respect for the rights of one's fellowman entails that some restrictions be placed upon these liberties necessarily. According to the International Covenant on Civil and Political Rights (ICCPR), a formally binding legal treaty ratified by 165 nations, fundamental and foundational human right must be protected by states. Most state constitutions protect rights for gathering anybody with other people for almost any reason: to express religious views, to protest, even to have a feast. But this doesn't mean anybody can do any of these things in any ways. People have the freedom to express their views in a group, but they can't disturb the public peace or infringe on anyone else's rights in the process. The right to freedom of expression is protected by The European Convention on Human Rights, Art. 10. Any limitation on the fundamental freedom must be provided by law, which is clear and accessible to everyone. With regard to devastating effects of terrorism on the enjoyment of the right to life, liberty and physical integrity of victims, because of terrorism Governments can be destabilized, civil society, peace and security can be undermined. So it clearly has a very real and direct impact on human rights. Regarding the rights which are inserted in The European Convention on Human Rights, two kind of limitation are mentioned (Article 15 of The European Convention on Human Rights). One of them is derogations which each state establish base on the law to protect individuals, security, morality and regularity in social especially about freedom of expression, Communities and religious statements and another one is the right of deviation or refrain from execution of rights which are mentioned in convention in time of war or other public emergency threatening the life of the nation (www.theguardian.com, 2012). States which wish to take advantage of this situation shall proclaim circumstances to Secretary General of Council of Europe accompanying full information, also it shall inform him when such measures have ceased to operate and the provisions of the convention are again being fully executed (Article 15,paragraph 3 of The European Convention on Human Rights). In July 2002, in Strasbourg Committee of Ministers of council of Europe at its 804th meeting adopted Guidelines on Human Rights and The Fight against Terrorism. The guidelines concentrate mainly on the limits to be considered and that States should not go beyond, under any circumstances, in their legitimate fight against terrorism (the guidelines on human rights and the fight against terrorism.p9). 
in paragraph 1 of article 3 it emphasized that all measures taken by states to combat terrorism must be lawful and in second paragraph it expressed that any restrictions to human rights must be defined as precisely as possible and be necessary and proportionate to the aim pursued. And about the measures which interfere with privacy is emphasized to provide law for measures like body search, house searches, bugging, telephone tapping, and surveillance of correspondence and use of undercover agents (article 6 .Para 1, Guidelines on Human Rights and The Fight against Terrorism, 2002). Because of the ever increasing danger and fear in connection to acts of terrorism, counterterrorism legislation often allows government officials to pass over typically required legal procedures, suspend previously guaranteed individual rights, generally, applying reduced judicial oversight. According to necessity and efficiency, and to pretext of national security, state officials are often given wide discretion to fight terrorism using any means available. As a result, counterterrorism legislation is particular unprotected to governmental overreach. In the lack of exact legal safeguards and clear instructions within the law, such laws can be, and probably have been, abused by state authorities to silence legitimate dissent.in 2006, in the United Kingdom, any public statements that incite any operation of terrorism, including statements that honoring specific terrorist acts, even if the individual or group making the statement did not actually intend to encourage terrorism, As the anti-terrorism law, was considered a crime. The law also broadly defines terrorism to include action taken to advance any 'political, religious, racial or ideological' cause designed to influence the government of any country or international organization or to intimate any member of the public anywhere in the world (the right to freedom of expression: restriction on a foundational right, global trends in NGO law, volume 6, issue 1, p11). In 2009, the British police were accused of misusing this and other counterterrorism related laws in an effort to quash otherwise peaceful protests. A one-year inquiry was launched, resulting in a 70-page report produced by the joint committee on human rights detailing evidence of abuse of police powers under the Terrorism Act (The Guardian, 2009). On the other hand because of Schengen Agreement, people can travel freely through 24 nations without border controls, also wave of migrants from Syria and other African countries that are at war cause wave of cheap labor and people seeking benefits from the poorer accession countries would flood the 15 established member states which are acute labor exploitation, or what one might call modern-day slavery. Take the cheap workers employed to clean private homes, or those who pick the fruit and vegetables from garbage cans.in this situation irregular migrants who try to access healthcare or education services, or seek justice in cases of abuse, often find closed doors. This condition is not only for migrants but also for Europe citizens. EU citizens who are made redundant are finding themselves forced to work in underpaid or even unpaid jobs, often in dangerous or unhealthy conditions. Also citizens who belong to minorities or second generation of migrants are under-represented even in sport. An Asian-British golf player from UK in an interview said: "A favorite technique of racist manifestations in golf relates to the manipulation of membership lists. Inquiries from Asian golfers are often met with the news that the membership list is full" (European Union Agency for Fundamental Rights, 2010). The available evidence produced by the research for five Member States showed that the overall participation of ethnic minorities and migrants in amateur sport low, especially among women and girls. Former football player, from Slovakia said: "I remember the case of a Roma coach who got from the 5th league to the 4th and then immediately to the 3rd, but was then dismissed without any explanation... It is hard for a Roma coach to get higher than the 3rd league" (European Union Agency for Fundamental Rights, 2010). This shows that the standards of justice and human rights protection in all countries and for all citizens in $\mathrm{EU}$ are not same.

\section{Future of human right in Europe}

There are some key questions about freedom facing Europe regarding fundamental rights in future. Adding new countries like former communist countries and turkey cause economic, social and political varied and complex which in addition to derogations arising from fight against terrorism, will affect on freedom and human right. Human rights come from where in that each citizen has a voice and can participate. The Italian writer Antonio Tabucchi said "Democracy isn't a state of perfection. It has to be improved, and that means constant vigilance". This can also be said of human rights (Kjaerum, 2012). Former Irish Prime Minister John Bruton said, the EU "is a guarantee of democracy, freedom, justice and human rights. Nations cannot stay in the EU if they do not respect these guarantees" (Kjaerum, 2012). The EU is open to all European countries (the TEU, Article 49) but in order to join the EU, each country must accept principles like freedom, democracy, respect for human rights and fundamental freedoms and the rule of law which emphasized in article 6(1). In this manner Italian Premier Mario Monty proposed a special European summit to confront growing populism in the face of the financial crisis. "We are in a dangerous phase," Monty said, "a divisive populism is present in nearly all Eurozone countries, and it aims to divide nations at a moment when the impetus is for greater integration....."(Kjaerum, 2012). It seems protection of fundamental freedoms and human right in future of EU depends on future extension of EU borders, adding new countries with new cultures and the degree of acceptance of human right principles by new countries that will 
join to EU and it will put pressure on the resources of its human rights enforcement mechanism, notably the European Court of Human Rights and the Office of the European Commissioner for Human Rights. The European Court of Human Rights is one of important pillars in protection of human rights.in addition to diversity in standards of protection of human right in EU countries; statements about separation from EU are heard in some countries. Statements from the UK on potential withdrawal from the European Convention on Human Rights are particularly worrying in this regard. Dean Spielmann, President of the Court, has said:" It would be a political disaster if any member state left the Convention. But it would be particularly disastrous if the UK pulled out, with its noble history of civil liberties [...] and while being responsible for promoting human rights all over the world"( Pearson, 2015). If England pulled out from the convention, it can create a domino effect of withdrawing from convention for other European countries, especially by countries which their standards in protection of human rights are weak and imperfect. Also it can to persuade the EU to reduce its standards of protection of human right because of trying to preserve the unity of Europe by leaders of European Union. Regarding to longer term future of the European Convention on Human Rights (ECHR), some measures are in processing. The Council of Europe is premotor of this process. The important point for success of the system is a court which must be strong and independent and able to providing definitive decisions and clear interpretation of the rights protected by the ECHR. This process must be evidence-based and should focus on achieving a truly shared responsibility for implementation of ECHR rights. At first needs to assess latest round of mutations completely than continue to reform. Obligation to more effective national implementation measures and better mechanisms for the implementation of judgments should be down in first step. Changes in domestic laws must be supported by States for insuring about policies and practices for the protection of individuals' rights at home. It will help to prevent of happening of violations in addition to divert cases away from the Court. This process must not ignore important developments in human rights law since 1950, and the significant role played by the ECHR. The case law of the European Court of Human Rights has not only helped improve the lives of individual applicants and change the shape of domestic law and policy across Europe, but it has helped judges across the world in better understanding the application of human rights principles in international law and in domestic constitutions.

\section{Conclusion}

Those principles of Human rights that are part of customary international law are applicable to all States but with regards to principles which are included in treaties those States that are party to a particular treaty having obligations under that treaty. In article 2 of the International Covenant on Civil and Political Rights emphasized that" Each State Party to the present Covenant undertakes to respect and to ensure to all individuals within its territory and subject to its jurisdiction the rights recognized in the present Covenant, without distinction of any kind, such as race, color, sex, language, religion, political or other opinion, national or social origin, property, birth or other status ".also lay stress on that if any country have not already provided any legislation or measures ,must take necessary steps to adopt such legislative or other measures. In any case, no country can avoid of protection of fundamental freedoms and human right in its territory because of international obligations which are binding for all states. But EU has higher standards in protection of human rights and executive guaranty about human rights law are more powerful than other countries. British withdrawal from the Union of Europe could be a model for other countries and lead to leaving the union Europe by more countries. This of course will have consequences for the protection of fundamental rights and human rights in such countries. Benefits and services of the EU are not applicable for Countries that are outside the Europe Union. One of these services is the European Court of Human Rights which its absence can lead to reduction of sanction or executive guaranty for violations of the fundamental rights and human rights in such countries. On the other hand, The rise of terrorist attacks in Europe, which have been lead to increased security measures and reduce individual freedoms and also The influx of immigrants from war-torn countries to Europe who Willing to work in different jobs outside the scope of labor laws of European countries, Under pressure capital owners, Encourages governments to revise labor laws for reduction of benefits and standards of labor. All these issues can lead to loss of human rights standards in EU. Also if the standards of human right reduce in Europe, Europe Union's leading role in the world in relation to human rights will lose. Therefore, with regards to the issues mentioned, it seems Human rights situation in the future is a threat for EU.

\section{References}

[1] Abasi Sarmadi, M. \&Nazari rad, A. (2012). European Court of Human Rights as a regional mechanism to support rights. Rasht, Iran, thesis, University of Guilan 
[2] Akhlaghi, B. \& Eshtiagh, V. \& Parvizian P. (2001). Europe Union Rights. Tehran, Iran, Shahre Danesh publication

[3] Alegre, S. (2008). Human Rights and the Future of the European Union.London, England, A Justice

[4] Amirardjmand, A. \& colleagues (2009). Collection of international documents on human rights". Tehran, Iran, jangale javedane publication

[5] European convention on human rights

[6] European Union Agency for Fundamental Rights. (2010). Racism, ethnic discrimination and exclusion of migrants and minorities in sport: The situation in the European Union. Summary Report,

[7] Ghaemmagham farahani, S. (2002). European human rights judicial procedures. Tehran, Iran, Avaya Noor publication

[8] Guidelines on Human Rights and the Fight against Terrorism, (2002).Council of Europe

[9] Hettne, B. (2001). the new regionalism: security and development

[10] http://www.humanrights.dk/research/human-rights-in-eu

[11] http://www.theguardian.com/law/2012/oct/10/human-rights-violations-european-union

[12] Kadkhodayi, A. (2001). The structure and the rights of the European Union. Tehran, Iran, mizan publication

[13] Kjaerum, M. (2012). Future for democracy and human rights in Europe. Seminar on the future for democracy and human rights in Europe

[14] Leach, P. (2005). Taking a Case to the European Court of Human Rights. Newyork, USA, Oxford university press, second edition

[15] Mehrpour, H. (2004). International system of human rights. Tehran, Iran, esla-aat publication

[16] Naghibi mofrad, H. (2010). Desire governance in the light of human rights globalization. Tehran, Iran, Shahre Danesh publication,

[17] Pearson, G. (2015). The Future of the European Court of Human Rights: Time to Focus on the Big Picture

[18] Sammer, J. (2002). European court of human rights and the united nation human rights committee, comparative studym, svu

[19] Seyed fatemi, S. (2000). New European Court of Human Rights.Iran, journal of law, no.25

[20] Sidabras \& dziautas v. Lithuania. nos 5548/00 and 59330/00, 27.7.04, para, 47.

[21] Taghizadeh Ansari, M. (2008). Europe Union Rights, Tehran, Iran, jangale javedane publication, preface

[22] The Guardian, (March 22, 2009). Police accused of misusing terror laws against peaceful protests. Available at http://www.theguardian.com/uk/2009/mar/23/police-terrorism-protest-g20-law.

[23] The right to freedom of expression: restriction on a foundational right, global trends in NGO law, volume 6 , issue 1

[24] The Treaty on European Union (The TEU), 